\title{
APPLICATION OF THE PRINCIPLES OF PROJECT MANAGEMENT IN THE PROCESS OF ONLINE MARKETING OF ACCOMMODATION FACILITIES
}

\author{
[Aplikace principů projektového řízení na proces online marketingu ubytovacích \\ zařízení]
}

\author{
Jitka Vávrová ${ }^{1}$ \\ ${ }^{1}$ Technická univerzita v Liberci, Ekonomická fakulta, Voroněžská 13, 46001 Liberec 1 \\ Email: jitka.vavrova@tul.cz
}

\begin{abstract}
The article discusses the possibility of application of project management principles to the process of online marketing in the Czech online competitive environment of accommodation facilities. The first part summarizes the basic principles of project management of major publications. Second part of the article introduces the reader to the topic of online marketing of accommodation facilities. A comprehensive model is showing various activities which were compiled by previous supporting research about online communication of accommodation facilities in the northern and eastern Bohemia. Last most important part of the article discusses the possibility of incorporating the principles of project management to the model shown. Proposed solution is finally potencialy applied to real accomodation facility.
\end{abstract}

Keywords: accomodation, internet marketing, online marketing, online marketing communication, project management, tourism.

JEL classification: M310

Doručeno redakci: 2.5.2016; Recenzováno: 17.5.2016; 3.6.2016; Schváleno k publikování: 24.8.2016

\section{Úvod}

Internetový marketing zaživá $\mathrm{v}$ posledních letech velký boom a pomalu začíná předhánět klasické marketingové nástroje $\mathrm{v}$ tradičních médiích. Konkrétně v České republice se objem prostředků vynaložených na internetovou reklamu dostal na třetí místo za televizní reklamu a tiskovou reklamu se sumou 6,5 miliard korun v roce 2013. Od roku 2012 byl zaznamenán nárůst o 19,3 \%. (Mediaresearch, 2013) Internetový marketing představuje jedno z nejdynamičtějších odvětví marketingu, které se mění prakticky každý den a oslovuje stále větši počet uživatelů. (Simkanič, Kolář, 2013) Firmy se snaží držet krok s tímto rychlým vývojem a vymýšlí stále nové metody komunikace svých produktů a služeb. Internet poskytuje zákazníkům širší výběr produktů a služeb a informuje je o situaci na trhu, o konkurenci, kvalitě zboží a zkušenostech jiných zákazníků. Mezi hlavní výhody online marketingu patří snadná př́stupnost potenciálním klientům po celém světě při jazykových mutacích, dále relativně nízké náklady, nepřetržitá nabídka - reklama viditelná 24 hodin denně, 365 dní v roce, možnost okamžité aktualizace obsahu sdělení, interakce a snadný vstup na mezinárodní trh za neměnnou cenu. (Czechtourism, 2014)

Problémem online marketingu ve firmách je ovšem jeho značná složitost, velké množství izolovaných nástrojů a mnoho možností, jak je ř́dit a zacházet s nimi. Teorie i praxe radí využívat reklamu na sociálních sítích, spravovat vlastní webové stránky, publikovat PR články, psát blogy, využívat PPC reklamu a hlavně aktualizovat všechny kanály a podřizovat je jednotné firemní strategii. Posledním současným trendem je tzv. content marketing, který se soustředí na poskytování hodnotných obsahových informací, třeba i interaktivního obsahu, který poutá pozornost. Základem je tvořit dlouhodobě kvalitní obsah a postupně budovat 
důvěru u obecenstva. (Online marketing, 2014, s. 153 - 154) Online marketing tedy dnes představuje složitý proces $\mathrm{s}$ mnoha prvky a podprocesy, který lze jen těžko bez organizace sjednotit a využívat efektivně. V tomto chaosu se nabízí ohlédnout se za základními principy projektového řízení a zvážit, zda by bylo možné je aplikovat na oblast řízení online marketingu ve firmách. Právě o tom pojednává tato vědecká stat', jejímž cílem je na základě teoretické rešerše a výsledků autorova výzkumu prozkoumat, zda je možné aplikovat principy projektového managementu na procesy současně intenzivně využívaného online marketingu. Rámcem pro tuto stat' je konkurenční prostř̌edí českých ubytovacích zařízení.

\section{1 Úloha projektového řízení ve firmě}

Projektový management je $\mathrm{v}$ současné době fenoménem, který je využíván stále více organizacemi bez ohledu na jejich velikost či zaměření. Doby, kdy pro management malých, středních nebo i velkých firem plně vyhovovaly liniové struktury řízení, jsou již za námi a jedním z projevů moderního managementu je orientace na moderní maticové organizační struktury. Rízení firem se nyní orientuje na procesy uvnitř firmy a vyžaduje pružnost a rychlost změny. Tuto teorii podporuje i výrazná potřeba firem se orientovat na své zákazníky, podřizovat jim veškerý chod firmy a vyrovnat se $\mathrm{s}$ tlakem trhu na rychlá rozhodnutí managementu a flexibilní vývoj nových produktů. $\mathrm{Na}$ podstatnou hodnotu projektového managementu a jeho složitost poukazuje ve své knize A. Svozilová (2011), která považuje projektový management za složitý komplex oblasti řízení, který nelze zjednodušit pouhou koncentrací na technické zvládnutí ovládání softwaru pro podporu řízení projektů. Mezi nejnáročnější, ale velmi důležité aktivity projektového řízení patří např.:

- transformace potřeb zadavatele do definovaného předmětu projektu

- vytváření odhadů a předpokladů a jejich přenos do plánů a metodických postupů

- vyjednávání o přidělení zdrojů pro projekt, zpracování podkladů pro jejich schválení

- vyhledávání pracovníků a obsazování pracovních rolí

- přidělování a koordinace jednotlivých úkolů

- vedení a motivace členů týmu

- vyvíjení a udržení prostředí žádoucí kvality

- kontrola průběhu projektových plánů

- monitorování potenciálních rizik, iniciace obranných opatření

- spouštění korigujících akcí

- zajištění předání výstupu projektu zadavateli

- vypořádání projektových agend

(Svozilová, 2011, s. 12-13)

Z výše uvedeného stručného výčtu aktivit projektového manažera vyplývá, že manažer projektu se musí vzdělávat nejen $\mathrm{v}$ jeho hospodářské oblasti působení, ale musí disponovat i znalostmi z projektového řízení, které musí neustále rozvíjet. Práci projektového manažera kromě samotné vysoké komplexity profese ztěžuje i neustále se dynamicky rozvíjející světová ekonomika, globalizace a moderní informační technologie. Tyto změny musí projektoví manažeři neustále sledovat, upravovat své postupy a reagovat na současný vývoj. Dynamika těchto změn způsobuje i změnu samotných postupů projektového managementu. Na vývoj teorie $\mathrm{v}$ moderním projektovém managementu mají vliv např. nadnárodní společnosti a měnící se požadavky řízení, rozsah a složitost současných projekti̊, agresivní tržní prostředí a nutnost okamžitých reakcí a dále i efektivní využívání mezinárodních odborníků i ve virtuálních týmech. Obecné základy projektového managementu se však nemění - stále se jedná o řídící metody a postupy aplikované na soubor zdrojủ, které tvoří lidé a jejich práce, peníze a jiné předměty materiální povahy, které jsou předpokladem vytvoření požadovaného předmětu, jenž vznikne společným působením těchto projektových zdrojů. (Svozilová, 2011, 
s. 12-13) Projektové řízení lze charakterizovat jako prostředek pro účinné a efektivní uskutečňování změn. Předmětem a cílem projektového řízení je úspěšná realizace projektu, který je chápán jako jedinečný proces, který se skládá z řady koordinovaných a plánovitě ř́zených činností s předem definovanými okamžiky zahájení a ukončení. Projekt je realizován za účelem dosažení stanoveného cíle, jež vyhovuje specifickým požadavkům při omezeních daných časem, náklady a zdroji. (ČSN ISO 10006)

\section{Projektový management a jeho využití}

Projektové řízení a jeho principy jsou využívány v celé řadě organizací a podniků. Některé organizace jsou řízené ryze projektově. Pro aktivity těchto organizací je typické, že jsou řízené formou procesů $s$ omezenou dobou trvání a dočasným přidělením zdrojů, tedy formou projektů. Existují dva základní typy těchto organizací, a to:

1. Takové organizace, které generují své výkony formou projektů realizovaných pro jiné organizace na bázi smlouvy. (stavební projekty, softwarové projekty apod.)

2. Takové organizace, které aplikují projektové řízení jako metodu řízení vnitřních operací. (vývoj nových produktů, marketing apod.)

Na výslednou podobu projektového řízení v konkrétní organizaci má vliv i její firemní kultura jako odraz sdílených hodnot a očekávání, užívaných pravidel a postupů, míra flexibility organizačních struktur, chápání autority nadřízených, vztah $\mathrm{k}$ novátorství a rizikovým úkolům, míra samostatnosti pracovníků, pracovní etika a odpovědnost za kvalitu, míra využívání pracovní doby a další. (Svozilová, 2011, s. 41)

V současné době je možné se setkat se škálou nejrůznějších opaření, standardů, norem a vyhlášek. Tyto standardy nutí pracovníky $\mathrm{k}$ tomu, aby plnili úkoly způsoby, na které nejsou zvyklí. Pracovníci přirozeně vůči těmto změnám často vykazují odpor. Pokud jsou navíc normy a standardy vytvářeny bez dostatečně ověřených zkušeností, představuje situace riziko ohrožující organizaci. Standardy projektového řízení jsou však v tomto ohledu zcela odlišné. Představují soubor metod a doporučení, které byly sestaveny dle nejlepších zkušeností manažerů a odborníků s nesčetnými praktickými zkušenostmi. Ve standardizaci projektového řízení je ovšem základním problémem různorodost a komplexnost prostoru, který tato problematika pokrývá. $Z$ tohoto důvodu nemohou být standardy projektového rrízení přesné v matematicko-technickém smyslu, ale jsou spíše sadou doporučení, jakou osvědčenou metodu zvolit. Jednotlivé standardy projektového managementu mají vždy podobnou základní filozofii a používají obdobné metody názvosloví. Pracovníci na jednotlivých projektech si většinou dokážou vzájemně porozumět a pochopit se, tedy i efektivně spolupracovat. (Doležal, Lacko, Máchal, 2009, s. 24 - 27)

\section{Základní principy řízení projektů}

Následující kapitola vymezuje základní pojmy projektového řízení a vysvětluje základní principy, které jsou ve všech standardech projektového řízení obdobné.

Základem projektu jsou vždy jeho konkrétní požadavky a cíle, které pochází od zadavatele projektu. Jsou důvodem pro existenci projektu. Proces návrhu a řízení požadavků spočívá v definici a odsouhlasení požadavků projektu takovým způsobem, který naplní potřeby a očekávání všech zainteresovaných stran - požadavky zadavatele projektu i účastníkủ projektu. Určování a definice těchto požadavků vychází z potřeb zadavatele (zákazníka), přičemž i jeho potřeby jsou iniciovány př́ležitostmi a riziky, které jsou zadavatelem vnímány. Cílem každého projektu je poskytnout zadavateli řešení a přidanou hodnotu oběma stranám. Definování cíle projektu je nejdůležitější částí plánování projektu. Jasná definice pomůže 
dobře naplánovat jednotlivé činnosti projektu a pomůže oběma stranám porozumět a ujasnit si, co bude konečným produktem, k čemu má sloužit a za jakých podmínek toho bude dosaženo. Pro definici hlavního cíle projektu i dílčích cílů se využívá pravidlo SMART (I), které tvrdí, že všechny cíle mají být svými vlastnostmi:

- $\mathrm{S}$ - specifické a specifikované

- M - měřitelné (projektový tým musí být schopen měřitelně zhodnotit stav splnění cíle)

- A - akceptované

- $\mathrm{R}$ - realistické

- T - termínované

- I - integrované (začleněné do organizace)

(Doležal, Lacko, Máchal, 2009, s. 58-63)

Řízení projektu je definováno jako proces. Rosenau (2000, s. 12-13) definuje pět kroků tohoto procesu, konkrétně pět odlišných manažerských činností:

1. Definování. Obsahuje definici projektových cílů.

2. Plánování. Specifické naplánování základní cesty, jak projektový tým splní definované cíle v rámci trojimperativu (specifikace provedení, časový plán a finanční rozpočet).

3. Vedení. Zahrnuje uplatňování manažerského stylu ř́zení lidských zdrojů, které povede k efektivnímu a včasnému vykonávání práce jednotlivých členů projektového týmu.

4. Sledování. Vyznačuje se monitorováním a kontrolou postupu projektových prací a vyhledáváním odchylek.

5. Ukončení. Představuje ověření splněných úkolů za daných podmínek, závěrečnou zprávu projektu a uzavření všech projektových úkolů a dokumentace.

Definování a plánování nemusí být vždy od sebe odděleno, ale může být jedním procesem. Tato situace je dokonce běžnější, než uvedení jasného definovaného cíle zadavatelem projektu. Častější je začátek s navrhnovanou pracovní definicí, která se znovu projednává během plánování. Při plánování se často objeví důsledky, které se následně do definice projektu prímo promítají. (Rosenau, 2000, s. 13)

V celém životním cyklu projektu se vyskytují tři parametry, které je třeba v projektu neustále monitorovat. Rosenau (2007) i další autoři v různých standardech definují tyto základní proměnné jako čas, náklady a kvalitu. Místo kvality se můžeme v literatuře potkat i s jinými parametry. Svozilová (2006) uvádí dostupnost zdrojů, Kerzner (2003) uvádí místo kvality výkon. Podle Wysockiho (2012) projekt nemůže být sledován pouze z pohledu tř́ parametrů, a proto základní parametry rozšiřuje také o rozsah a zdroje. I přes odlišnosti v přesné definici těchto parametrů autoři zdůrazňují základní princip úplné provázanosti jednotlivých parametrů. Změna $v$ jednom parametru způsobí vždy odraz v parametru jiném.

Už z výše uvedené definice projektu vyplývá, že každý projekt se vykazuje svým specifickým začátkem a koncem. Co se děje mezi těmito dvěma body, je pro každý projekt individuální proces. I přes jedinečnost každého projektu se však autoři shodují, že lze životní cyklus projektu zobecnit a definovat jednotlivé fáze. Doležal, Lacko a Máchal (2009) rozčleňují životní cyklus projektu $\mathrm{z}$ manažerského hlediska na fázi předprojektovou, projektovou a poprojektovou. Rosenau (2007) rozlišuje fázi počáteční, prostřední a závěrečnou. Jednotlivé fáze a jejich model by však měl být uzpůsoben v procesu plánování konkrétního projektu dle konkrétních parametrů a omezení projektu a organizace. 


\section{Od marketingu $k$ projektovému řízení}

Vzhledem k současné vysoké pružnosti trhu se úloha marketingu stále více přesouvá ke koordinování pohotové reakce celé firemní organizace. Čím rychleji a důsledněji je marketing schopen přenášet tržní impulsy na celou organizaci, tím lepší je reakceschopnost celé organizace. Na trh nastupuje nová generace firem, jejichž úspěch je založen na tzv. totálním marketingovém řízení. Základem uvedeného př́stupu je jasně definovaná marketingová filozofie, znalost trhu, organizace podř́zzená marketingové strategii, předstih v rozhodování a důsledná finanční měřitelnost prŕínosu marketingových aktivit. Bureš (1992) definuje tzv. marketingový algoritmus, který se skládá z činností, které na sebe logicky navazují a tvoří metodu systematického uvádění podnikatelských nápadů na trh. Součástí algoritmu je i zpětná vazba, která má být hybnou pákou celé organizace a zamezuje nežádoucí setrvačnosti. (Bureš, 1992, s. 7, 69-72) Realizace marketingově ř́zené organizace může být postavena na procesním prrístupu $\mathrm{k}$ managementu. Důvodem pro přechod k procesnímu řízení je opět schopnost reagovat na odlišné a stále se vyvíjející požadavky zákazníků. Procesní př́stup představuje důsledné nasazení specifických metod do všech úrovní organizace při zachování vzájemného sladění cílů. Prostřednictvím procesního managementu se na organizaci nahlíží jako na systém vzájemně provázaných procesů, které souvisí se třemi základními oblastmi: perfektní znalost vlastních procesủ, verifikace činností pro přeměnu vstupů na výstupy, monitorování výkonnostních ukazatelů a zlepšování. Procesní rrízení se zabývá integrací samostatných prací do logických celků, delinearizací prací, uplatňováním týmové práce, odpovědností pracovníků za proces a variantním pojetím procesu (Grasseová, 2008, s. 42-43).

Ve výše uvedené literatuře se autoři shodují na podobných principech řízení firmy, které se soustředí na pružnost v konkurenčním prostředí. Pokud se řízení marketingu prolíná celou organizací, tak je samotná kvalita tohoto řízení velmi důležitá. Otázkou zůstává, mohou marketingoví manažeři využít principy projektového řízení a přineslo by jim to usnadnění aplikace procesního řízení marketingu $\mathrm{v}$ praxi? $\mathrm{V}$ současné literatuře nenajdeme mnoho tendencí $\mathrm{k}$ propojení principů marketingu a projektového řízení. Např́iklad článek o šesti klíčových bodech spojení projektového marketingu a projektového managementu od autorů Cova a Salle (2005) propojuje tyto disciplíny z unikátního pohledu a naznačuje důležitost marketingu samotného projektu. Nezabývá se však využitím projektového řízení pro základní procesy marketingu. I tak ale článek nabízí zajímavé srovnání šesti disciplín projektu z pohledu projektového marketingu a projektového managementu:

Tabulka 1: Šest klíčových bodů spojení projektového marketingu a projektového managementu

\begin{tabular}{|l|l|l|}
\hline Disciplína (klíčový bod) & Projektový management & Projektový marketing \\
\hline Projekt & Dočasná organizace & Transakce \\
\hline Charakteristické rysy projektu & Specifické časové rámce a cíle & $\begin{array}{l}\text { Diskontinuita mezi jinými } \\
\text { projekty }\end{array}$ \\
\hline Cyklus projektu & Začíná žádostí nebo návrhem & $\begin{array}{l}\text { Začíná ve vnějším prostředí } \\
\text { projektovou př́ležitostí }\end{array}$ \\
\hline Zaměření přístupu & $\begin{array}{l}\text { Zdroje jsou určeny k posílení } \\
\text { vztahư uvnitř jednoho projektu }\end{array}$ & $\begin{array}{l}\text { Zdroje jsou určeny k udržení } \\
\text { vztahu mezi dvěma projekty }\end{array}$ \\
\hline Zainteresované strany & $\begin{array}{l}\text { Vnitřní a vnější zúčastnění, kteří } \\
\text { mohou mít vliv na vývoj projektu }\end{array}$ & $\begin{array}{l}\text { Vztahy mezi obchodními a } \\
\text { neobchodními zúčastněnými v } \\
\text { prostředí projektu }\end{array}$ \\
\hline Původ projektu & Většinou dán & \begin{tabular}{l} 
Dán nebo společně konstruován \\
\hline
\end{tabular} \\
\hline
\end{tabular}

Zdroj: Cova a Salle (2005) 
Oba př́stupy - projektový management a projektový marketing - cílí na tvorbu jedinečného a specifického procesu. Projektový management se ovšem více vyznačuje dočasností a naopak projektový marketing se soustředí také na dlouhodobé důsledky projektu pro zadavatele. Projektový marketing poskytuje novou širší perspektivu pro projektový management a obohacuje jej o tvorbu a udržování vzájemných vztahů zadavatele projektu a projekt realizující firmy.

\section{Metodika}

Pro zamyšlení se nad možnou aplikací principů projektového řízení na základní úlohy marketingu je nutné nejprve definovat konkrétní prostředí. Každá organizace či firma je jiná, jiné jsou její požadavky a jiné jsou i marketingové aktivity. Lze předpokládat, že firmy podobné velikosti a podobného zaměření budou mít i své marketingové aktivity podobného rázu a celkový model by tedy mohl být postaven na podobných principech. Tento článek pracuje s prostředím českých firem provozujících malá nebo střední ubytovací zařízení, jako jsou hotely, chaty, penziony, turistické ubytovny a další podobná zařízení. Marketingové chování těchto firem a př́stup $\mathrm{k}$ zákazníkủm byl prozkoumán $\mathrm{v}$ projektu zabývajícím se modelem online komunikace se zákazníkem v oblasti ubytovacích služeb. Protože byl tento projekt zaměřen především na řízení online marketingu v těchto firmách, tak se i tento článek orientuje na online marketing, který je dle výsledků proběhlého výzkumu $\mathrm{v}$ těchto firmách upřednostňován před tradičními médii. Respondenty byli majitelé a manažeři ubytovacích zařízení v krajích severovýchodních Čech, konkrétně v kraji Libereckém, Královéhradeckém a v Ústeckém. Výzkum byl realizován prostřednictvím online dotazníku. Cílem projektu bylo zmapovat všechny nástroje internetové komunikace firem v odvětví ubytovacích služeb, jejich využití v těchto firmách a na základě výsledků $\mathrm{z}$ dotazníkového šetření byl sestaven model online komunikace se zákazníky, který popisuje, jak těchto prostředků využívat co nejefektivněji. Výzkum mapoval také to, v jaké fázi získávání či zpracování zakázky je vhodné začlenit určitý nástroj online komunikace a jak jej využít nejlépe. Celkově tedy tento model popisuje všechny podstatné aktivity online marketingu ve zkoumaných firmách.

Celkem se ve třech sledovaných krajích nachází 2835 ubytovacích kapacit. Bylo osloveno $60 \%$ z nich. Celková návratnost při počtu 356 odpovědí činila 20,92\%. Jednotlivé kategorie klasifikace byly v celkovém počtu 356 respondentů zastoupeny následovně:

- 17 chatových osad $(4,8 \%)$

- 47 hotelů $(13,2 \%)$

- 12 kempů $(3,4 \%)$

- 138 penzionů $(38,8 \%)$

- 43 turistických ubytoven (12\%)

- 99 zařízení jiného nespecifikovaného typu (27,8\% - typ zařízení nebyl specifikován a nebylo ho možné zařadit do žádné $z$ výše uvedených kategorií, jedná se o různé horské chaty, fary, hostely apod.)

Následující obrázek demonstruje sestavený model online komunikace se zákazníkem v oblasti ubytovacích služeb. 
Obrázek 1: Model online komunikace se zákazníkem v odvětví ubytovacích služeb

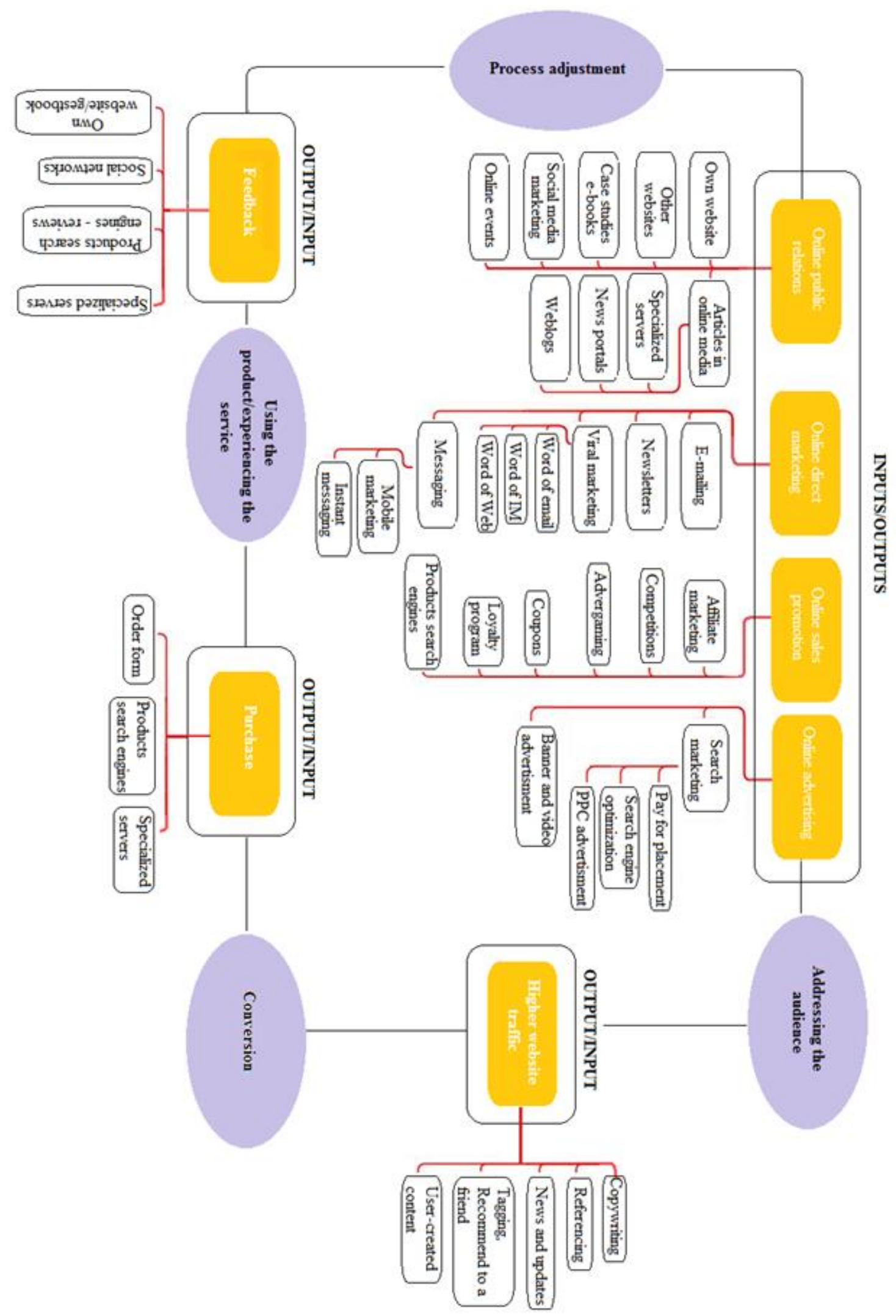

Zdroj: vlastní zpracování 
Výše znázorněný model popisuje proces jednotlivých aktivit online marketingu u zkoumaných firem. Jednotlivé podružné marketingové aktivity jsou souhrnně zařazeny do několika hlavních skupin, a to online vztahy s veřejností (správa webových stránek, propagace na jiných webových stránkách, e-knihy, př́tomnost na sociálních sítích, online události, články $\mathrm{v}$ online médiích, specializované servery a portály, blogy), online př́mý marketing (e-mailing, newslettery, virální marketing, elektronické word of mouth, mobilní marketing či messaging), online podpora prodeje (affiliate marketing, konkurence, advergaming, kupony, programy zákaznické loajality, produktové vyhledávače) a online reklama (reklama na vyhledávačích, optimalizace pro vyhledávače, pay-per-click reklama, bannerová a video reklama). V modelu nesmí chybět ani skupina aktivit starající se o vyšší návštěvnost webových stránek (copywriting, reference, updaty, tagy, uživatelský obsah), skupina zajišt'ující samotný prodej služeb online (objednávkový formulár̆, produktové vyhledávače, specializované servery) a skupina zjišt’ující zpětnou vazbu od zákazníků (specializované servery, recenze na vyhledávačích produktů, sociální sítě, vlastní návštěvní kniha na webu). Lze předpokládat, že tento model skutečně mapuje veškeré možné aktivity, které může v rámci online marketingu firma vykonávat. Provedený výzkum ukázal, že mezi jednotlivými aktivitami existují vazby a že celý model vykazuje procesní chování.

Správou online marketingu se dle výsledků výzkumu zabývá v 56\% sám majitel ubytovacího zařízení, u $21 \%$ za správu zodpovídá jeden konkrétní zaměstnanec, u $14 \%$ se jedná o více zaměstnanců. Pouze v $9 \%$ je správa svěřena externímu odborníkovi nebo externí firmě. $Z$ těchto výsledků lze usuzovat, že malé a střední firmy provozující ubytovací zařízení nemají př́liš zájem o outsourcing odborné správy online komunikačních nástrojů a namísto toho preferují interní řízení.

\section{Využití principů projektového managementu v řízení online marketingu}

Je možné považovat marketingový proces za projekt? Přinese tento pohled nějaký př́nos pro marketingového manažera? Před zodpovězením těchto otázek je nutné však nejprve posoudit, zda jde skutečně o projekt $\mathrm{v}$ pravém slova smyslu, přičemž existují dva základní případy, které je nutné vzít v úvahu:

1. Online marketing ubytovacího zařízení je v externí správě (externí firma, odborník).

2. Online marketing ubytovacího zařízení je v interní správě (majitel firmy, zaměstnanec, skupina zaměstnanců).

Rosenau (2000, s. 5) tvrdí, že existují čtyři typické znaky projektů, které, pokud se vyskytují společně, odlišují ŕízení projektu od jiných manažerských činností. Projekty jako takové mají mít trojrozměrný cíl (tj. současné splnění požadavků na věcné provedení, časový plán a rozpočtové náklady), jsou jedinečné (provádí se pouze jednou a jsou dočasné), mají zdroje (lidské a materiální) a realizují se v rámci organizace.

V prvním př́ípadě, kdy je online marketing ubytovacího zařízení v externí správě, tak se jednoznačně jedná o projekt, který je řízen externím odborníkem, marketingovým manažerem. Jednotlivé znaky projektu vysvětluje následující tabulka: 
Tabulka 2: Posouzení online marketingu jako projektu, externí správa

\begin{tabular}{|c|c|}
\hline $\begin{array}{l}\text { Trojrozměrný cíl (tj. současné } \\
\text { splnění požadavků na věcné } \\
\text { provedení, časový plán a rozpočtové } \\
\text { náklady) }\end{array}$ & $\begin{array}{l}\text { Hlavním obecným cílem projektu správy online marketingu by } \\
\text { mohlo být obecně zvýšení zisku firmy, které by mělo být } \\
\text { konstatováno na určitou měřitelnou úroveň. Cíl mǔže být dán i } \\
\text { zvýšením objemu prodeje, proniknutím na nové trhy apod. Podružné } \\
\text { cíle mohou signalizovat strategie, kterými lze tento hlavní cíl } \\
\text { dosáhnout. Cíl je trojrozměrný - věcné provedení značí splnění } \\
\text { navýšení zisku, časový plán je ohraničen dobou pưsobnosti } \\
\text { externího manažera a rozpočtové náklady na marketingové plány } \\
\text { jsou rovněž stanoveny. }\end{array}$ \\
\hline Jedinečnost a dočasnost & $\begin{array}{l}\text { Jak již bylo vysvětleno, dočasnost projektu je dána časovou } \\
\text { působností externího manažera. Pro externího manažera je projekt } \\
\text { skutečně jedinečný, protože je veden za specifických podmínek, } \mathrm{V} \\
\text { konkrétním roce, konkrétní ekonomické situaci a s jedinečnými cíli. } \\
\text { Není žádoucí, aby se úplně stejné marketingové plány prováděly } \\
\text { několikrát za sebou, i kdyby se nezměnil zákazník. }\end{array}$ \\
\hline Zdroje (lidské a materiální) & $\begin{array}{l}\text { K projektu jsou přiřazeny zdroje lidské - externí odborník } \\
\text { (odborníci) a další zúčastnění, kterými mohou být spolupracující } \\
\text { firmy a agentury a zaměstnanci ubytovacího zař́zení. Při řízení } \\
\text { projektu je nutné sestavit projektový tým s jasně danou organizační } \\
\text { strukturou a rozdělením kompetencí. Tento tým nemusí kopírovat } \\
\text { tým marketingový. Materiálními zdroji mohou být reklamní } \\
\text { předměty a další podstatné materiály pro projekt. }\end{array}$ \\
\hline Realizace v rámci organizace & $\begin{array}{l}\text { Projekt je realizován v rámci organizace externí firmy nebo v rámci } \\
\text { organizace ubytovacího zařízení ve spolupráci } \mathrm{S} \text { externím } \\
\text { odborníkem. Hranice mezi jednotlivými organizacemi by se zde } \\
\text { měly prolínat a v projektovém týmu by měla být účast obou stran. }\end{array}$ \\
\hline
\end{tabular}

Zdroj: vlastní zpracování.

$\mathrm{V}$ druhém prŕípadě, kdy je online marketing řízen majitelem firmy nebo více zaměstnanci firmy je situace už složitější. Posouzení jednotlivých znaků projektu obsahuje následující tabulka.

Tabulka 3: Posouzení online marketingu jako projektu, interní správa

\begin{tabular}{|c|c|}
\hline $\begin{array}{l}\text { Trojrozměrný cíl }(\mathrm{tj} . \text { současné } \\
\text { splnění požadavků na věcné } \\
\text { provedení, časový plán a rozpočtové } \\
\text { náklady) }\end{array}$ & $\begin{array}{l}\text { Základním faktorem projektového řízení je přítomnost } \\
\text { jednoznačného cíle v projektu, který by měl být jasný a pokud } \\
\text { možno měřitelný. I marketingový manažer by měl mít stanovený } \\
\text { jednoznaćný dlouhodobější cíl, kterého chce s pomocí } \\
\text { marketingových aktivit dosáhnout. Takovým cílem může být } \\
\text { zvýšení podílu na trhu, vyšší zisk, vyšší objem prodeje nebo } \\
\text { podobně (v konkrétní měřitelné výši). Tento cíl by se měl snažit } \\
\text { splnit v určitém časovém plánu a za splnění rozpočtových nákladù, } \\
\text { které by měly být také stanovené předem. Trojrozměrnost cíle je } \\
\text { tedy přenositelná i na teorii marketingového managementu v } \\
\text { případě interní správy. }\end{array}$ \\
\hline Jedinečnost a dočasnost & $\begin{array}{l}\text { Jedinečnost a dočasnost projektu (správy online marketingu) je } \\
\text { dána jedinečnou situací na trhu, jedinečným cílem a dočasnost je } \\
\text { dána časovým omezením projektu a rozpočtových nákladů. Projekt } \\
\text { interní správy online marketingu je tedy jedinečný a dočasný. }\end{array}$ \\
\hline Zdroje (lidské a materiální) & $\begin{array}{l}\text { K projektu jsou přiřazeny jak lidské, tak materiální zdroje. Lidské } \\
\text { zdroje představuje marketingový tým (opět s jasně danou } \\
\text { organizační strukturou) nebo samostatně pracující manažer (majitel } \\
\text { firmy) a materiální zdroje jsou stejné jako v př́ípadě externí správy } \\
\text { (reklamní předměty apod.). }\end{array}$ \\
\hline Realizace v rámci organizace & $\begin{array}{l}\text { Projekt interní správy online marketingu je realizován } \mathrm{v} \text { rámci } \\
\text { organizace }-\mathrm{v} \text { rámci konkrétního ubytovacího zařizení. Tento bod } \\
\text { je tedy také splněn. }\end{array}$ \\
\hline
\end{tabular}


Řízení online marketingu interně ve vlastní firmě bez externího odborníka by tedy mělo také vykazovat znaky projektového řízení. Proběhlý výzkum však ukázal, že reálně manažeři nepoužívají tyto zásady projektového managementu a svou práci řídí spíše intuitivně, bez dlouhodobých i krátkodobých plánů. Cíle mnohdy nejsou vůbec stanovené a rozpočtové náklady rovněž. Tato situace představuje $\mathrm{v}$ praxi velký problém, který by měl být řešen a manažeři a majitelé ubytovacích zařízení a jiných malých a středních firem by měli být o tomto problému informování a měli by se vzdělávat $\mathrm{i} v$ principech projektového řízení. Představuje to i možný podnět pro další výzkum, který by porovnával úspěšnost online marketingových aktivit $\mathrm{s}$ využitím principů projektového řízení a bez. Výsledky takového výzkumu by poskytly jednoznačnou odpověd'.

Využití principů projektového řízení pro základní marketingové procesy by mohlo představovat významnou inovaci $\mathrm{v}$ oblasti firemního a marketingového plánování, ale i v oblasti implementace navržených strategií a v ř́zení marketingu. Struktura aktivit by se proměnila a získala by procesní charakter, který by mohl přispět $\mathrm{k}$ lepší přehlednosti prací a i k omezení jejich př́ípadné redundantnosti. Zavádění projektového řízení do marketingově ř́zené organizace by mohlo představovat i kvalitní nástroj pro realizaci jednotlivých marketingových plánů. Cooper a Lane (1999, s. 73-75) definují strategické cíle firmy jako úkoly, které chce firma splnit v rámci jednoznačně vymezeného času. Strategické cíle bývají určovány pro delší časové období - střednědobé (5 let), dlouhodobé (10 - 15 let). Při určování strategie je nutné stanovit také cíle dílčí, které jsou odvozené od navržené strategie a od cíle střednědobého nebo dlouhodobého. Autoři však specifikují rovněž cíle marketingové, které jsou určovány tak, aby napomáhaly dosažení strategických cílů. Z hlediska marketingově řízené společnosti by však strategické a marketingové plánování nemělo být odděleno. Pro využití projektového řízení by dle dílčích cílů bylo možné napřs. sestavit několik krátkodobých taktických projektů, které by byly obsaženy v jednom souhrnném dlouhodobém projektu.

\section{Př́ípadová studie}

Pro názornost navrhovaných změn $\mathrm{v}$ přístupu $\mathrm{k}$ řízení marketingu $\mathrm{z}$ hlediska projektového řízení obsahuje článek konkrétní př́ípadovou studii. Tato studie demonstruje, jak by bylo možné aplikovat principy této inovace na reálnou organizaci. Studie je založena na reálném př́ípadu hotelu v chráněné krajinné oblasti. Hotel má kapacitu 103 lůžek a průměrná roční návštěvnost je 2000 hostů. Roční obrat hotelu se pohybuje v rozmezí 3 - 5 milionů Kč. Správou online marketingu se zabývá výhradně sám majitel ubytovacího zařízení, přičemž $\mathrm{k}$ propagaci hotelu využívá hlavně online marketing. Majitel odpověděl, že investice do online marketingu jsou vzhledem k obratu pro něj spíše drobnější a nevýznamné, a že se mu tyto investice jednoznačně vrací. Z online komunikačních nástrojů využívá vlastní webové stránky, online cestovní agentury, vyhledávače ubytování, e-mail, PPC reklamu, slevové portály, objednávkový formulář na vlastním webu a návštěvní knihu na vlastním webu. Majitel si je vědom základů strategického marketingového plánování, má zpracovanou základní SWOT analýzu vlastního podnikatelského prostředí a jeho cílem je zvýšení průměrné roční návštěvnosti hotelu na 3000 hostů v horizontu 5 - 10 let. Majitel předpokládá, že poptávka ubytování v této chráněné krajinné oblasti je dostatečně vysoká a usiluje o to, aby firma lépe vynikala $\mathrm{v}$ místním konkurenčním prostředí. Řízení online marketingu však probíhá pouze intuitivně, bez organizace práce. Majitel sleduje nové trendy v oblasti online marketingu a snaží se je spontánně aplikovat na své aktivity. Zatím ovšem výsledky jeho aktivit nevykazují takovou pridanou hodnotu, jakou by dle stanoveného cíle měly.

Jaké kroky by tedy měl majitel podniknout, kdyby chtěl zavést principy projektového řízení na řízení online marketingu? Rosenau (2000) definuje proces řízení projektu v 5 krocích: 


\section{Definování.}

Majitel by měl definovat v první řadě dílčí cíle jeho marketingových aktivit. Definice pouze jedinného cíle $\mathrm{v}$ podobě zvýšení průměrné roční návštěvnosti $\mathrm{v}$ horizontu 5 - 10 let je nedostatečná. Stanovení dílčích cílů by měla předcházet důkladná analýza využití a efektivity jednotlivých komunikačních nástrojů. S ohledem na výsledky analýzy by bylo možné stanovit dočasné cíle, např̀. pro horizont čtvrtletí nebo i kratší. Tyto dočasné cíle by měly firmu dovést $\mathrm{k}$ dlouhodobému cíli.

\section{Plánování.}

S ohledem na trojimperativ projektového řízení (specifikace provedení, časový plán a finanční rozpočet) by měla přijít fáze plánování strategií, jak dosáhnout vytyčených cílů. Nejen s ohledem na marketingové aktivity, ale i s ohledem na vnější prostředí projektu - tedy i s ohledem na zlepšení kvality služeb hotelu a jiné inovace, které by přispěly k vyšší spokojenosti zákazníků.

\section{Vedení.}

Dalši fází je případné delegování části prací podřízeným a jejich následné manažerské vedení.

\section{Sledování.}

Ve fázi sledování by měl majitel monitorovat a kontrolovat postup prací svých i prací podř́zených, průběžné výsledky aktivit a př́padně vyhledávat odchylky a upravovat jednotlivé strategie.

\section{Ukončení.}

Ačkoli je $\mathrm{v}$ teorii projektového ř́zení pouze jedna fáze ukončení, zhodnocení dosažených výsledků projektu a další, tak pro proces řízení online marketingu by bylo vhodné zařadit i dílčí ukončovací fáze pro dílčí cíle. Jelikož je řízení online marketingu neustále se měnícím odvětvím s občas nepředvídatelným chováním, kontrolní a ukončovací fáze by měly být častější než u jiných projektů.

Tato inovace by majiteli pomohla lépe organizovat marketingové aktivity firmy a poskytla by firmě nová data a informace. Díky zavedení projektového řízení by se dala očekávat i vyšší efektivita online marketingu. Vzhledem $\mathrm{k}$ tomu, že projektové řízení je tradičně podpořeno softwarovými nástroji, tak by bylo vhodné pro manažery podobných nástrojů $\mathrm{k}$ řízení marketingu také využít.

\section{Závěr}

Cílem tohoto článku bylo posoudit, zda je možné aplikovat principy projektového řízení na základní marketingové procesy, především v online marketingu, a zda by to přineslo přidanou hodnotu. I když jsou zde tyto principy diskutovány pouze nad př́padem ubytovacích zařízení, tak je pravděpodobné, že i situace $\mathrm{v}$ jinak zaměřených firmách by mohla být podobná. I samotná teorie marketingového plánování, teorie marketingově řízených firem i základy procesního řízení vykazují velkou podobnost s principy projektového rrízení. Projektové ř́zení však může představovat jedinečný funkční rámec až na operativní úrovni, který pomáhá manažerům $\mathrm{v}$ organizaci jejich práce. $\mathrm{V}$ článku bylo prostřednictvím teoretických i praktických porovnání prokázáno, že je možné ř́dit online marketing ve firmě jako projekt a na prrípadové studii byly navrženy žádoucí změny dle diskutovaných faktů. Do budoucna by bylo zajímavé se aplikací principů projektového řízení na proces online marketingu zabývat více a projít jednotlivé principy a fáze podrobněji. Další otázkou k řešení je také potenciální možnost integrace izolovaných marketingových komunikačních nástrojü, která by mohla vyřešit problém redundantních prací a nejednoty jednotlivých marketingových aktivit. Tuto teorii by mohl podpořit i praktický výzkum, který by zjišt'oval úspěšnost manažerů využívajících principy projektového řízení a těch, kteří je nevyužívají. 


\section{Literatura}

[1] BUREŠ, I., 1992. Marketingově ř́zená firma: filozofie, organizace, strategie: autorovy zkušenosti z Kanady a USA. Praha: Management Press. ISBN 80-85603-24-1.

[2] COVA, B. a R. SALLE, 2005. Six key points to merge project marketing into project management. International Journal of Project Management [online]. 23(5), 354-359 [cit. 2016-01-28]. ISSN 0263-7863. DOI: 10.1016/j.ijproman.2005.01.006. Dostupné z: linkinghub.elsevier.com/retrieve/pii/S0263786305000190

[3] Czechtourism, 2014. Využití internetu a vyhledávání informací českými uživateli. Czechtourism [online]. [vid. 2016-1-28]. Dostupný z: old.czechtourism.cz/didaktickepodklady/5-cestovani-a-internet/

[4] ČSN ISO 10006. Systémy managementu jakosti - Směrnice pro management jakosti projekti̊. Praha: Český normalizační institut.

[5] DOLEŽAL, J., B. LACKO a P. MÁCHAL, 2009. Projektový management podle IPMA. 1. vyd. Praha: Grada. ISBN 978-80-247-2848-3.

[6] GRASSEOVÁ, M., R. DUBEC a R. HORÁK, 2008. Procesní ř́zení ve veřejném sektoru: teoretická východiska a praktické př́klady. Brno: Computer Press. ISBN 97880-251-1987-7.

[7] KERZNER, H., 2003. Project management: a systems approach to planning, scheduling, and controlling. 8th ed. New York: Wiley. ISBN 04-712-2577-0.

[8] Mediaresearch, 2013. Mediatypy v letech 2012 a 2013: ceníková hodnota reklamy na internetu i nadále roste, na TV trhu nastal $8 \%$ pokles. Mediaresearch [online]. [vid. 2016-1-28]. Dostupné z: www.mediaresearch.cz/aktualita/tz-admosphere-mediatypy-vletech-2012-a-2013-cenikova-hodnota-reklamy-na-internetu-i-nadale-roste-na-tv-trhunastal-8-pokles

[9] ROSENAU, M. D., 2000. Řizení projekti̊. Praha: Computer Press. ISBN 80-7226-218-1.

[10] ROSENAU, M. D., 2007. Řizení projekti̊. Brno: Computer Press. ISBN 978-80-2511506-0.

[11] SIMKANIČ, J. a P. KOLÁ̌̌, 2013. Internet advertising conference [online]. [vid. 201628-1]. Dostupné z: i.iinfo.cz/files/iac/582/jan-simkanic-1.pdf

[12] SVOZILOVÁ, A., 2006. Projektový management. Praha: Grada. ISBN 80-247-1501-5.

[13] SVOZILOVÁ, A., 2011. Projektový management. 2., aktualiz. a dopl. vyd. Praha: Grada. ISBN 978-80-247-3611-2.

[14] WYSOCKI, R., 2000. Effective project management. New York: J. Wiley. ISBN 04713-6028-7. 